\title{
Students' Multirepresentation Ability in Completing Physics Evaluation Problems
}

\author{
Rambu Ririnsia Harra Hau ${ }^{1}$, Paulina Nelce Mole ${ }^{2}$, Agustina Elizabeth ${ }^{3}$, Yohanes Sudarmo \\ Dua $^{4}$, Maria Yani Leonarda ${ }^{5}$ \\ Universitas Nusa Nipa Maumere, Indonesia ${ }^{1,2,3,4,5}$ \\ ramburirinsia12@gmail.com ${ }^{1}$, paulinnel19@gmail.com², ma.agustinaelizabeth @gmail.com³, \\ profdua021288@gmail.com ${ }^{4}$, nanileonarda15@gmail.com ${ }^{5}$
}

Received: August $15^{\text {th }}, 2020$. Revised: September $2^{\text {nd }}, 2020$. Accepted: September $3^{\text {rd }}, 2020$

\section{Keywords :}

Multirepresentation Ability; Physics Evaluation Questions; Problem Solving

\begin{abstract}
This study aims to describe students' multi-representation ability in solving physics evaluation questions carried out by the qualitative description method in class X MIA 1 SMA Katolik St. Gabriel Maumere for the 2019/2020 school year. The data were obtained from the matter of physics evaluation on Newton's law material about the force of gravity. Data analysis is based on student work steps in solving evaluation questions. Data analysis results show that the ability of multi-representation in solving physics problems on Newton's law material about the force of gravity in the high category. The number of mathematical representations of $100 \%$, image representation of $10 \%$, then in the medium type only uses a mathematical description of $100 \%$ and in the low category using a mathematical representation of $100 \%$ and a verbal representation of $40 \%$.
\end{abstract}

\section{INTRODUCTION}

Physics is one of the subjects in high school in the field of scientific specialization. Studying physics requires a variety of student representations or multiple representations in understanding a problem [1]. Education is a process that is carried out deliberately in order to increase knowledge, insight and experience [2]. Education serves to create a quality generation. According to Irwandi [3], there are five crucial reasons why multi-representation is needed to use in physics learning. First, each student's intelligence background is different, so it is necessary to apply multi-representation knowledge to provide optimal learning opportunities for students. Second, physics concepts that occur in everyday life can be better visualized and understood by using representations, Third, to help construct other, more abstract representations. Fourth, to help learners' qualitative reasoning, concrete representations can be utilized; Fifth, students' quantitative argument can be assisted by abstract representations to make it easier for students to solve quantitative questions.

Teachers can measure the student's ability to complete various tests given by the teacher; this means that the examination given by the teacher must be a test that can measure students' multi-representation skills. According to Prakoso et al. [4], the requirements for a multi-representation question can solve complex problems, and the concept must be presented clearly in all forms. It will be easier to measure students' 
Students' Multirepresentation Ability in Completing Physics Evaluation Problems Rambu Ririnsia Harra Hau, Paulina Nelce Mole, Agustina Elizabeth, Yohanes Sudarmo Dua, Maria Yani

multi-representation abilities by using essay tests rather than multiple choice. This is because the essay test requires students to describe, organize, and state answers in their own words in different forms, techniques, and styles [5]. The essential thing about science is collaboration between concept and practice various representations for one concept [6].

Previous research on multi-representation analysis has been carried out by several researchers, including Nulhaq and Utari [7], who examined the profile of students' multi-representation abilities on sound material using structured description tests and limited essay tests. Based on his research, it was concluded that the students' multi-representation ability was better when working on a formal analysis than on a limited essay test. This is because the structured description test leads students to the concepts of representation. Research on students' multi-representation abilities was carried out by Thesy et al. [8] High and low category students have an accurate use of graphical representation (G) of $83 \%$ and $77.78 \%$, and medium category has proper use of image representation (D) equal to $66 \%$. Nopitasari [9] found that students who had high initial mathematical abilities were able to present solutions with verbal, symbolic, and visual representations (graphs). Students can offer solutions with verbal and symbolic representations. In contrast, students who have low initial mathematical abilities can only write interpretations of representation but do not understand symbolic and visual representations (graphics).

Although the strength of multi-representation is very important to be mastered by students in learning physics, the teachers' tradition in giving questions that are able to measure students' multi-representation ability is classified as very low. This can be seen, among others, that the form of questions used during the Final Semester Examination is dominated by mulitemsice questions. This situation was also found at St. Gabriel Maumere Catholic High School in the 2019/2020 school year. Based on the perspective of measuring students 'multi-representation abilities, the essay questions prepared by the teachers are expected to be able to measure students' multi-representation abilities. So it is necessary to do a more in-depth study of the ability of students' multi-representation on physics evaluation questions at St. Gabriel Catholic Senior High School Maumere Therefore This study aims to describe the multirepresentation ability of students in solving physics evaluation questions carried out Physics is one of the subjects in high school in the field of scientific specialization.

\section{METHOD}

This study and the data collection based on qualitative research that reveals a phenomenon that occurs in the world [10] [11]. Object of this study is multi-representation ability which is taken from the midsemester exam questions about Newton's law material about gravitational force and student answer sheets and in-depth interviews with students. The subjects in this study were eighteen students of class X MIA 1 SMA St. Gabriel. Analysis data based on steps evaluating exam from the answer key then was categorized by standar devisiasi therefore will be divided consist of 3 category, the high category with the initials S1, the medium category S3 and the low category S5 respectively [12].

\section{RESULTS AND DISCUSSIONS}

The multi representation ability of students in solving mid-semester evaluation questions about Newton's law material about gravitational force was obtained from the results of the analysis using the scoring rubric of multi representation abilities (table 1). Suci and Zubaidah [13] reported Multirepresentation learning had a great impat to improve the students' understanding about Newton's. Based on the percentage of students' multi representation ability in solving Newton's law questions about the force of gravity in the high, medium and low categories, it can be seen that students tend to use mathematical representations rather than verbal and image representations and even don't use graphical representations at all. This shows that students in solving the questions refer to the mid-semester evaluation questions which are more on the mathematical representation and the way students solve the 
questions as seen from the student answer sheets illustrating the students' multi-representation ability.

Table 1. Students' Multirepresentation Abilities In Completing Evaluation Questions

\begin{tabular}{ccccc}
\hline Category & \multicolumn{4}{c}{ Representation } \\
\cline { 2 - 5 } & Verbal & Graphs & Drawing & Mathematical \\
\hline High & $0 \%$ & $0 \%$ & $10 \%$ & $100 \%$ \\
Medium & $0 \%$ & $0 \%$ & $0 \%$ & $100 \%$ \\
Low & $40 \%$ & $0 \%$ & $0 \%$ & $100 \%$ \\
\hline
\end{tabular}

Students' multi-representation ability in solving Newton's law questions about the force of gravity in the high category.

High category students in solving problem 1 calculate the magnitude of the gravitational force between two objects with a mass of $5 \mathrm{~kg}$ and $4 \mathrm{~kg}$ and separated by a distance. From the results of the work, the $\mathrm{S} 1$ subject has been able to clearly identify what is known and what is asked and write formulas using the right symbols. Even though you have used the equation correctly, the calculation results obtained are not correct with what was asked and the solution to question number 1 presents one type of representation, namely using a mathematical representation. According to Hau et al, [10] the pattern of mathematical representation ability starts from writing known and asked symbols, writing equations, using physical quantities of quantities, substituting quantities into equations, performing calculations and final answers. Therefore, in this situation the students already understand the questions given and know the information that is known such as the mass of the first object, the mass of the second object, the distance and the constant gravity in the form of symbols and what is asked is the amount of gravitational force which in physics is symbolized by $\mathrm{F}$, and using the equation for the force of gravity correctly. Students choose to use symbolic representations in communicating or conveying their mathematical ideas.

In Problem number 2, determine the location of object $\mathrm{C}$ from objects $\mathrm{A}$ and $\mathrm{B}$ so that the gravitational force acting on object $\mathrm{C}=0$ between two objects with a mass of $1 \mathrm{~kg}$ and $4 \mathrm{~kg}$ and separated at a distance. $\mathrm{S} 1$ identifies questions by presenting data using more than one different type of representation. This can be seen from the completion process at the stage of identifying what the S1 subject knows by using symbols and using image representations. Mason and Singh [14] reported that students who have images ability for the multiple-choice questions will have great performance rather than students who do not. Interestingly in this research we found only $10 \%$. Furthermore, to identify what the S1 subject asked about using verbal representations. The S1 problem solving stage presents data in the form of a mathematical representation then rewrites using a verbal representation of the final answer from the calculation results, namely the location of object $\mathrm{C}$ must be $2 \mathrm{~m}$ from object $\mathrm{A}$ and object $\mathrm{B}$ that is visible on the worksheet. After conducting interviews with $\mathrm{S} 1$ subjects, they said that the information known from the questions included mass of object A $1 \mathrm{~kg}$, mass of object B $4 \mathrm{~kg}$, mass of object C $2 \mathrm{~kg}$ and distance (r) $1 \mathrm{~m}$ then represented the problem again in the form of an image, using the force equation gravity, students also said that the calculation was unable to determine the quantity of physics correctly in deciphering the equation.

Problem number 3 aims to make students able to calculate the weight of an object that weighs $100 \mathrm{~N}$ when it is on the surface of the earth, taken to planet $X$ which has a mass 10 times the mass of the earth and a radius twice the radius of the earth. From the results of the S1 work, identify and solve questions using mathematical representations so that they can make known and asked magnitude symbols that are also able to understand the concept well. This can be seen in writing the correct equations and performing calculations using good mathematical knowledge by knowing the relationship between concepts and being able to calculate the physical quantities in the process of solving them. In line with the statement of the students when being interviewed, S1 said the same thing that in solving the questions they were able to identify what was known and asked from the questions and had also used the gravity equation so that they obtained results that matched what was asked, namely.

Problem number 4 students calculate the ratio of the gravitational field strength of objects A and B which have radius $\mathrm{R}$ and mass $\mathrm{M}$ and $2 \mathrm{M}$ with the positions of the earth's surface $\mathrm{R}$ and $2 \mathrm{R}$. The results 
Students' Multirepresentation Ability in Completing Physics Evaluation Problems Rambu Ririnsia Harra Hau, Paulina Nelce Mole, Agustina Elizabeth, Yohanes Sudarmo Dua, Maria Yani

Leonarda

of the work of the S1 subject are obtained in identifying questions. S1 subjects make mathematical symbols correctly, but write wrong equations and calculations. This problem student's present data using only one type of representation, namely a mathematical representation.

Problem number 5 determines the ratio of the acceleration due to gravity on the surface of planet $X$ and the surface of the earth, where the mass of the planet $X$ is $1 / 2$ times the mass of the earth and the radius $1 / 4$ times the radius of the earth. Problem number 5 determines the ratio of the acceleration due to gravity on the surface of planet $X$ and the surface of the earth, where the mass of the planet $X$ is $1 / 2$ times the mass of the earth and the radius $1 / 4$ times the radius of the earth. S1 subjects also use the correct equation so that in performing calculations students are able to calculate the quantity of physics correctly. In identifying and solving question number 5 the $\mathrm{S} 1$ subject presents data in the form of a mathematical representation.

Based on the results of the overall research on the S1 subject, it can be seen that an overview of the multi-representation of students in solving questions tends to use mathematical representations rather than image representations and verbal representations. Similar with research from Marwan and Duskri [15] which states that students who have high abilities and are understanding the problems given, are able to represent the problems given in a mathematical form, are able, communicate problem solving and are appropriate in making calculations. High achievement in school has relation with problemsolving which lead to the higher-order thinking skills [16]. Problem-solving method, reuires students to apply their knowledge and skills to obtain specific goals and apply their abilities and rules to solve any problems [14] [17].

The students' multi-representation ability in solving Newton's law questions about the force of gravity in the medium category.

Students in the medium category in terms of question number 1, the results of the S3 subject's work show that they are not able to identify the questions well. This is because the S3 subject is only able to write the symbol of the scale that is known in the form of a verbal representation or words, namely the object weight I $5 \mathrm{~kg}$ and the second object weight $4 \mathrm{~kg}$ without writing the symbol being asked. Furthermore, S3 writes the equation for the gravitational force correctly and performs the correct calculation without writing down the units using a mathematical representation. The results of the interview, the $\mathrm{S} 3$ subjects state that the steps in solving problems, namely first writing are known, asked and answered. The results of the interview which stated that it is known from the problem that the mass of object I is $1 \mathrm{~kg}$, object mass II is $4 \mathrm{~kg}$, distance (r) $20 \mathrm{~cm}$ and the determination of gravity and is asked from the problem, namely the force of gravity or $\mathrm{F}$ and uses the equation for the gravitational equation for Newton $F=G \cdot \frac{m_{1} \cdot m_{2}}{r^{2}}$.

In solving physics, especially on the law, Newton is the most important part of learning physics. Therefore, a measuring tool in the form of an assessment to measure ability is important to do. In the assessment, it must consist of the concept of reading, selecting, and applying complex procedures [18]. Judging from question no $2 \mathrm{~S} 3$ is not able to identify the problem so that the subject makes known symbols using verbal representations, namely object I, object II, and a distance of $1 \mathrm{~m}$. Subject S3 does not bring up an image representation in the answer but directly uses a mathematical representation by writing equations. Even though the S3 subject has used the equation correctly but in calculating the results of the calculations obtained are not exactly in accordance with what was asked and did not write down the units. In line with the results of the interview, Subject S3 stated that what is known from the problem, namely and the distance with the equation used, is the Newton gravity equation.

The students' multirepresentation ability in solving Newton's law questions about the force of gravity in the low category. Problem number 3 S3 does not make the symbols known and asked but writes the equation correctly but does the wrong calculation. This means that $\mathrm{S} 3$ understands the concept in the problem but their math skills are still lacking. Likewise for questions number 4 and 5 students understand the questions, it appears that they do not write down what is known and asked but write 
down the equations being asked. Mathematical calculations are still not correct and correct.

The general description of students' multi-representation in solving problems tends to use mathematical representations rather than image representations and verbal representations. This is in line with research from Nasliyah [19] at SMA Negeri 7 Pontianak showed that in preparing physics questions students tend to use one or two representations. Approximately $92.22 \%$ of students formed a mathematical representation, but only $17.78 \%$ of students had the correct answer. This data shows that the use of a single representation, namely a mathematical calculation strategy alone cannot support success in solving problems. The ability to solve the physics problem of Newton's law is one of the goals in learning physics. For that reason, an assessment instrument is needed to measure that ability. The assessment instrument should require students to organize, select, and apply complex procedures [16].

The students' multi-representation ability in solving Newton's law questions about the force of gravity in the low category.

Evaluation question number one, S5 identifies questions and solves questions using more than one different type of representation, namely images and mathematics. Seen to write a known magnitude symbol using verbal representations or words without writing down the symbol being asked. S5 also represents the problem in picture form and writes mathematical numbers. S5 has understood the context of the questions but has not yet reached the evaluation stage so it seems that they did not write down the units. This is in line with the results of the interview, the subject stated that there are two known objects with a mass of $5 \mathrm{~kg}$ and $4 \mathrm{~kg}$, a distance of $20 \mathrm{~cm}$ and gravity. $\mathrm{S} 5$ explains that the first step is to rewrite the problem later, reinterpret the problem in the form of a picture using the gravitational force formula and solve the problem based on the formula to get the result. problem number 3, Subject S5 does not make mathematical symbols but directly uses mathematical representations in writing equations. wrong in using the equation so that the results obtained do not match what was asked.

As a whole, it is known that the general description of students' multi-representation in solving questions tends to use mathematical representations rather than image representations and verbal representations. From the results of tests and interviews conducted with students in the low category, it was found that these students were less able to identify questions. Low category students made mistakes in forming mathematical representations such as question number 2 incorrectly determining formulas and doing calculations. Yusuf and Setiawan [20] stated that students prefer calculation questions (75\%) than conceptual questions. When trying to solve a problem, they look for a suitable formula according to the information they can find out from the problem. If they don't find (don't remember) a formula that works, then they decide to give up. Hau and Nuri [21] stated that conceptual understanding is one of the core competencies in physics lessons. Studying physics students must have the ability to understand a physics concept and explain the relationship between these concepts and apply these concepts correctly and precisely in a physics problem. Therefore, concept formation is a representation that students have in solving various physics problems.

\section{CONCLUSION AND SUGGESTION}

Based on the results and discussion, it can be concluded that the ability of multi-representation in solving physics problems on Newton's law material about the force of gravity in the high category. The number of mathematical representations of $100 \%$, image representation of $10 \%$, then in the medium type only uses a mathematical description of $100 \%$ and in the low category using a mathematical representation of $100 \%$ and a verbal representation of $40 \%$.

\section{ACKNOWLEDGMENTS}

Thanks to the UNIPA Physics Education Study Program for taking the time and opportunity for researchers to carry out this research, and Kemenristek Dikti for funding assistance for the smooth running of this research. 
Students' Multirepresentation Ability in Completing Physics Evaluation Problems Rambu Ririnsia Harra Hau, Paulina Nelce Mole, Agustina Elizabeth, Yohanes Sudarmo Dua, Maria Yani

\section{REFERENCES}

[1] Prahani, B. K., Nur, M., \& Yuanita, L. (2015). Student's self confidence in physics learning. Seminar Nasional Fisika (SENAFIS), Jember.

[2] Mansur, S., \& Bare, Y. (2019). Meningkatkan Hasil Belajar Siswa pada Konsep Perubahan dan Pelestarian Lingkungan Hidup dengan Model Discovery Learning di SMAS Katolik ST Gabriel Maumere. BIOEDUSCIENCE: Jurnal Pendidikan Biologi dan Sains, 3(2): 84-89.

[3] Irwandani, I. (2014). Multi Representasi sebagai Alternatif Pembelajaran dalam Fisika. Jurnal Ilmiah Pendidikan Fisika Al-BiRuNi, 3(1): 39-48.

[4] Prakoso, B. E., Djudin, T., \& Hamdani, H. (2019). Analisis Kemampuan Multirepresentasi Peserta Didik Dalam Mengerjakan Soal Gerak Lurus Berubah Beraturan Di SMA. Jurnal Pendidikan dan Pembelajaran Khatulistiwa, 8(6).

[5] Arifin, Z. (2009). Evaluasi Pembelajaran. Bandung: PT Remaja Rosdakarya.

[6] Murtono, M., Setiawan, A., \& Rusdiana, D. (2014). Fungsi Representasi dalam mengakses penguasaan konsep fisika Mahasiswa. JRKPF UAD, 1(2): 80-84.

[7] Nulhaq, S., \& Utari, S. (2013). Analisis Profil Kemampuan Multirepresentasi Siswa Berdasarkan Hasil Tes Uraian pada Materi Bunyi di SMP. WaPFi (Wahana Pendidikan Fisika), 1(1).

[8] Theasy, Y. (2018). Multi-representation ability of students on the problem solving physics. JPhCS, 983(1): 012005.

[9] Nopitasari, D. (2017). Analisis kemampuan multi representasi matematis berdasarkan kemampuan awal matematis mahasiswa. Pedagogy: Jurnal Pendidikan Matematika, 2(1).

[10] Hau, R. R. H., Marwoto, P., Putra, N. M. D., \& Wiyanto, W. (2018). Deskripsi Kemampuan Representasi Matematik dalam Pemecahan Masalah Fisika pada Perkuliahan Listrik Magnet. Physics Communication, 2(1): 1-17.

[11] Creswell, J. W. (2010). Mapping the developing landscape of mixed methods research. SAGE handbook of mixed methods in social \& behavioral research, 2: 45-68.

[12] Hau, R. R. H., Marwoto, P., \& Putra, N. M. D. (2018, March). Pattern of mathematic representation ability in magnetic electricity Problem. In International Conference on Mathematics and Science Education IOP Conf. Series: Journal of Physics: Conf. Series (Vol. 983).

[13] Furwati, S., Sutopo, S., \& Zubaidah, S. (2017). Conceptual Understanding and Representation Quality through Multi-representation Learning on Newton Law Content. Jurnal Pendidikan Sains, 5(3): 80-88.

[14] Mason, A., \& Singh, C. (2010). Helping students learn effective problem solving strategies by reflecting with peers. American journal of physics, 78(7): 748-754.

[15] Sulastri, S., Marwan, M., \& Duskri, M. (2017). Kemampuan representasi matematis siswa SMP melalui pendekatan pendidikan matematika realistik. Beta: Jurnal Tadris Matematika, 10(1): 5169.

[16] Slavin, R. E. (2018). Educational Psychology: Theory and Practice. New York: Pearson.

[17] Robertson, S. S. (2016). Problem Solving: Perspectives from Cognition and Neuroscience. Philadelphia: PA: Psychology Press.

[18] Supeno, S., Subiki, S., \& Rohma, L. W. (2018). Students' Ability In Solving Physics Problems on Newtons' Law of Motion. Jurnal Ilmiah Pendidikan Fisika Al-Biruni, 7(1): 59-70.

[19] Nasliyah, A. B. N. (2018). Efektivitas Model Pembelajaran Sains Teknologi Masyarakat Terhadap Keterampilan Proses Sains fisika siswankelas XI SMAN 3 Makassar (Doctoral dissertation, Universitas Islam Negeri Alauddin Makassar).

[20] Yusuf, M., \& Setiawan, W. (2009). Studi kompetensi multirepresentasi mahasiswa pada topik elektrostatika. Jurnal Pendidikan Teknologi Informasi dan Komunikasi, 2(1): 1-10.

[21] Hau, R. R. H., \& Nuri, N. (2019). Pemahaman Siswa terhadap Konsep Hukum I Newton. Variabel, 2(2): $56-61$. 